\author{
Mediterranean Journals \\ Integrative Journal of Medical Sciences \\ 2021, Volume 8, ID 445 \\ DOI: $\underline{10.15342 / i j m s .2021 .445}$
}

REVIEW

\title{
Possibilities and Considerations on the Use of ECMO as a Therapeutic Option for Patients with Acute Respiratory Distress Syndrome due to Viral Infections
}

\author{
Abderrahmane Bakkali (D) a, Hind El Yacoubi ${ }^{\text {b }}$, Najib Al Idrissi (iD c , Rochd Sayah ${ }^{\text {b d }}$, Mohamed Laaroussi ${ }^{\text {b d }}$ \\ ${ }^{\text {a }}$ Faculty of Medicine and Pharmacy, Ibn Zohr University, Agadir, Morocco. \\ ${ }^{\mathrm{b}}$ Faculty of Medicine and Pharmacy, Mohammed V University, Rabat, Morocco. \\ ${ }^{\mathrm{c}}$ Faculty of Medicine and Pharmacy, University Mohammed VI for Health Sciences, Casablanca, Morocco. \\ ${ }^{\mathrm{d}}$ Cardiovascular Surgery Department, Ibn Sina hospital, Rabat, Morocco.
}

\begin{abstract}
Management of acute respiratory distress syndrome due to viral outbreaks includes lower tidal volumes, lower inspiratory pressure, prone ventilation, and conservative fluid management. Extracorporeal membrane oxygenation (ECMO) has been proposed as rescue therapy in critically ill patients. However, in the absence of larger studies, the role of ECMO in reducing patient mortality rates remains unclear since studies that reported such effect, both during the current as well as during previous outbreaks, were based on small sample sizes, and their results are inconsistent. Furthermore, the use of ECMO might even be contraindicated in the presence of some conditions. Recurring to it has, therefore, to be discussed by qualified multi-disciplinary teams and based on a case-by-case strategy.
\end{abstract}

KEYWORDS: Extracorporeal Membrane Oxygenation; Extracorporeal Life Support; Acute Respiratory Distress Syndrome; Viral Outbreak.

Correspondence: Abderrahman Bakkali. Faculty of Medicine and Pharmacy, Ibn Zohr University, Agadir, Morocco. Email: drbakkaliabd@yahoo.fr

Copyright () 2021 Bakkali A et al. This is an open access article distributed under the Creative Commons Attribution 4.0 International, which permits unrestricted use, distribution, and reproduction in any medium, provided the original work is properly cited.

\section{How ECMO works?}

ECMO, also known as extracorporeal life support, is a form of cardiopulmonary support that may be indicated in cases of reversible acute severe cardiac or pulmonary failure unresponsive to conventional management.

Two main types of ECMO :veno-venous-ECMO, which provides respiratory support and can replace the gas exchange function of the lungs and minimize ventilator-induced lung injury, barotrauma, and oxygen toxicity; and veno-arteriel- ECMO, which provides both respiratory

and hemodynamic support[4].

ECMO does not provide direct support for organs other than the lungs or heart beyond increasing systemic oxygen delivery and mitigating ventilator induced lung injury [3].

The principle of ECMO is to collect the patient's venous blood into a pump connected to an oxygenator and restore the oxygenated and decarboxylated blood to the patient via a great vein (Veno-Veinous ECMO) or via a great artery (Veno-arteriel ECMO).

Currently, ECMO remains a complicated and high risk therapy; therefore, it requires adequate training and a well-qualified intensive care unit team

The World Health Organization Guidelines of ARDS Management

Currently, the WHO strategies on managing ARDS include lower tidal volumes $(4-8 \mathrm{~mL} / \mathrm{kg}$ predicted body weight), lower inspiratory pressure (plateau pressure $<30$ $\mathrm{cmH} 20$ ), prone ventilation greater than 12 hours, and conservative fluid management. Use of ECMO has been advised for consideration in expert centers for patients who have refractory hypoxemia despite lung-protective ventilation [5].

EOLIA and CESAR Trials

The randomized EOLIA (ECMO to rescue acute lung injury in severe ARDS) trial involving patients with 
severe acute respiratory distress syndrome stated that the analysis of the primary endpoint (mortality at 60 days) showed no significant benefit of early ECMO as compared with conventional mechanical ventilation; however, ECMO is safe and not associated with significantly higher mortality than standard management. When used as a rescue modality, ECMO may help improve survival in patients that would otherwise probably died [6-8].

In the CESAR trial (Randomized controlled trial and economic evaluation Controlled Trial of Conventional Ventilatory Support vs. Extracorporeal Membrane Oxygenation for Severe Adult Respiratory Failure), a large multicenter randomized trial comparing consideration for ECMO versus conventional therapy for treating severe acute respiratory failure in adults, 180 patients were enrolled from 68 centers throughout the United Kingdom over a 5-year period (2001-2006). Ninety patients were randomized to consideration of ECMO, and 90 to continued conventional treatment. The results from this trial showed that the primary endpoint, survival to 6 months without disability, was significantly reduced in the ECMO group compared to the conventional treatment group (63\% versus $47 \%$; relative risk $[\mathrm{RR}]$ 69; $(95 \%$ confidence interval [CI] 05$.097) ; p=.03$ ) and support the use of ECMO in appropriately selected patients with life threatening acute respiratory failure [9-10].

\section{Previous Experience of ECMO during Escalating Outbreaks}

Since ECMO was proposed in the management of ARDS, it was considered as therapy of viral-related respiratory failure.

During the Influenza A (H1N1) pandemic of 2009, the benefits of ECMO in the management of ARDS were uncertain and controversial. Holzgraefe et al. and Pham et al. suggested that ECMO for H1N1 2009-related respiratory failure may have a favorable outcome $[11,12]$. Noah et al. found a mortality rate of $52.5 \%$ in ECMO group versus $27.5 \%$ in non-ECMO group [13], whereas Shinhiro et al. reported a survival rate of $35.7 \%$ in a cohort of 14 patients and concluded that ECMO therapy for H1N1-related severe respiratory failure has very poor outcomes [14].

In turn, ECMO therapy during the Middle Eastern respiratory syndrome (MERS) outbreak appeared to be beneficial. Veno-Venous-ECMO use as rescue therapy was associated with lower mortality in severely hypoxemic patients who failed optimal ventilation strategies [15].

\section{ECMO Use during COVID19 Pandemic}

ECMO has been applied for refractory respiratory or cardiac failure secondary to severe myocarditis in COVID-19 patients [4]. WHO has recommended that consideration should be given to referring COVID-19 patients with refractory hypoxemia to expert centers capable of providing extracorporeal membrane oxygenation (ECMO) [16].
Extracorporeal Life Support Organization (ELSO) has provided selection criteria for ECMO referral. Patients who are under optimal ventilation strategies, neuromuscular blockade, appropriate PEEP, prone positioning, and pulmonary vasodilators and develop the following conditions: $\mathrm{PaO} 2 / \mathrm{FiO} 2$ less than $50 \mathrm{mmHg}$ less than 3 hours or $\mathrm{PaO} 2 / \mathrm{FiO} 2$ less than $60 \mathrm{~mm} \mathrm{Hg}$ for greater than 6 hours, or $\mathrm{pH}$ less than 7.20 and $\mathrm{PaCO} 2$ greater than $80 \mathrm{mmHg}$ for less than 6 hours, may be suitable for ECMO referral whenever there is no contraindication [17].

Though there are no clinical trials of ECMO in COVID19 patients, $11.5 \%$ of Chinese COVID-19 cases in the intensive care unit received ECMO [18]. Early cohort studies reported mortality of COVID-19- patients undergoing ECMO ranging from 42 to $94 \%$. Zeng et al. reported a mortality rate of $41.7 \%$ in 12 COVID-19 patients with hypoxemic respiratory failure placed on ECMO [19]. In a cohort of 234 cases of COVID-19 related ARDS, 17 (7.25\%) received ECMO, the mortality rate was $94.1 \%$ in ECMO group compared with $70.9 \%$ in non-ECMO group [20].

Thus, the role of ECMO in the management of ARDSrelated to COVID-19 is unclear. However, we think that, in the presence of the endotheliopathy due to the infection, which activates inflammatory immune reaction and pulmonary vascular microthrombosis [19-20], the use of ECMO, which increases the inflammatory statute and the risk of coagulopathy, may be useless and even harmful.

\section{CONCLUSION}

To date, the role of ECMO in the management of ARDSrelated viral outbreaks is unclear and controversial. In the absence of unanimous evidence of proven benefit, the decision to initiate ECMO in ARDS-related viral outbreak has to be discussed case by case by a high qualified multi-disciplinary team. The presence of endotheliopathy should be carefully assessed, and avoiding ECMO in its presence should be considered.

\section{ACKNOWLEDGMENTS}

None.

\section{AUTHORS' CONTRIBUTIONS}

The participation of each author corresponds to the criteria of authorship and contributorship emphasized in the Recommendations for the Conduct, Reporting, Editing, and Publication of Scholarly work in Medical Journals of the International Committee of Medical Journal Editors. Indeed, all the authors have actively participated in the redaction, the revision of the manuscript, and provided approval for this final revised version.

\section{COMPETING INTERESTS}

The authors declare no competing interests with this case.

\section{FUNDING SOURCES}

None. 


\section{REFERENCES}

[1] Paules CI, Marston HD, Fauci AS. Coronavirus infections-more than just the common cold. JAMA.2020;323(8):707-708. DOI: 10.1001/jama.2020.0757

[2] Wu C, Chen X, Cai Y, Xia J, Zhou X, Xu S et al. Risk factors associated with acute respiratory distress syndrome and death in patients with coronavirus disease 2019 pneumonia in Wuhan, China. JAMA Intern Med.2020;180(7):934-943.

DOI: $10.1001 /$ jamainternmed.2020.0994

[3] Mac Laren C, Fisher D, Brodie D. Preparing for the most critically ill patients with COVID-19, the potential role of extracorporeal membrane oxygenation. JAMA. 2020;323(13): 1245-1246.

DOI: $\underline{10.1001 / \text { jama.2020.2342 }}$

[4] Pravda NS, Pravda MS, Koronowski R, Orvin K Extracorporeal membrane oxygenation therapy in the COVID-19 pandemic. Future Cardiol. 2020.

DOI: $10.2217 /$ fca-2020-0040

[5] World Health Organization. Clinical management of severe acute respiratory infection when novel coronavirus (2019-nCoV) infection is suspected: interim guidance 2020. WHO/2019-nCoV/clinical/2020.4. Available: https://www.who.int/publications-detail-redirect/clinicalmanagement-of-covid-19

[6] Combes A, Hajage D, Capellier G, Demoule A, Lavoué S, Guervilly $\mathrm{C}$ et al. Extracorporeal membrane oxygenation for severe acute respiratory distress syndrome. N Engl J Med. 2018; 378(21): 1965-1975. DOI: $10.5935 / 0103-507 X .20190077$

[7] Sameed M, Meng Z, Marciniak ET. EOLIA trial: the future of extracorporeal membrane oxygenation in acute respiratory distress syndrome therapy? .Breathe. 2019; 15 : 244-246. DOI: 10.1183/20734735.0363-2018

[8] Kulkarni T, Sharma NS, Diaz-Guzman E. Extracorporeal membrane oxygenation in adults: A practical guide for internists. Cleve Clin J Med 2016; 83: 373-384. DOI: $10.3949 /$ ccjm.83a.15021

[9] Peek GJ, Mugford M, Tiruvoipati R, Wilson A, Allen E, Thalanany MM et al. Efficacy and economic assessment of conventional ventilatory support versus extracorporeal membrane oxygenation for severe adult respiratory failure (CESAR): A multicentre randomized controlled trial Lancet. 2009; 374:1351-63.

DOI: 10.1016/S0140-6736(09)61069-2

[10] Sidebotham D. Extracorporeal membrane oxygenationunderstanding the evidence: CESAR and beyond. J Extra Corpor Technol. 2011; 43(1): 23-26. Available: https://pubmed.ncbi.nlm.nih.gov/21449236/

[11] Holzgraefe B, Broomé M, Kalzèn H, Konrad D, Palm-r K, Frenckner. Extracorporeal Membrane Oxygenation for Pandemic H1N1 2009 Respiratory Failure. Minerva Anestesiol2010 Dec; 76(12):1043-51. Available: https://pubmed.ncbi.nlm.nih.gov/21178913/

[12] Pham T, Combes A, Rozé H, Chevret S, Mercat A, Roch A et al. Extracorporeal membrane oxygenation for pandemic influenza $\mathrm{A}(\mathrm{H} 1 \mathrm{~N} 1)$-induced acute respiratory distress syndrome: a cohort study and propensity-matched analysis. Am J Respir Crit Care Med. 2013; 187(3): 276285. DOI: $10.1164 / \mathrm{rccm} .201205-0815 \mathrm{OC}$
[13] Noah MA, Peek GJ, Finney SJ, Griffiths MJ, Harrison DA, Grieve $\mathrm{R}$ et al. Referral to an extracorporeal membrane oxygenation center and mortality among patients with severe 2009 influenza A(H1N1). JAMA. 2011; 306(15):1659-1668 DOI: 10.1001/jama.2011.1471

[14] Shinhiro T, Toru K, Satoshi N, Shingo I, Toshiyuki A, Ryoichi $\mathrm{O}$ et al. Extracorporeal Membrane Oxygenation for 2009 Influenza A (H1N1) Severe Respiratory Failure in Japan. J Anesth. 2012; 26(5):650-7. DOI: $10.1007 / \mathrm{s} 00540-012-1402-\mathrm{x}$

[15] Alshahrani MS, Sindi A, Alshamsi F, El Tahan M, Alahmadi B et al. Extracorporeal membrane oxygenation for severe Middle East respiratory syndrome coronavirus. Ann Intensive Care.2018; 8(1):3. DOI: $10.1186 / \mathrm{s} 13613-017-0350-\mathrm{x}$

[16] World Health Organization. Clinical management of severe acute respiratory infection when novel coronavirus (2019-nCoV) infection is suspected-interim guidance. Published January 28, 2020. Available: https://www.who.int/publications-detail-redirect/10665332299

[17] Extracorporeal life support organization COVID-19 interim guidelines. Available: https://www.elso.org/COVID19.aspx

[18] Yang X, Yu Y, Xu J,Shu H, Xia J, Liu H et al. Clinica course and outcomes of critically ill patients with SARSCoV-2 pneumonia in Wuhan, China: a single-centered, retrospective, observational study. Lancet Respir Med. 2020; 8(5): 475-81. DOI: $10.1016 / \mathrm{S} 2213-2600(20) 30079-5$

[19] Zeng Y,Cai Z, Xianyu Y,Yang BX, Song T, Yan Q. Prognosis when using extracorporeal membrane oxygenation (ECMO) for critically ill COVID-19 patients in China: aretrospective case series Critical Care. 2020; 24: 148 . DOI: $10.1186 / \mathrm{s} 13054-020-2840-8$

[20] Henry BM, Lippi G. Poor survival with extracorporeal membrane oxygenation in acute respiratory distress syndrome (ARDS) due to coronavirus disease 2019 (COVID-19): pooled analysis of early reports. J Crit Care. 2020; 58:27-28 DOI: $10.1016 /$ j.jcrc.2020.03.011

[21] Klok FA, Kruip MJHA, van der Meer NJM et al. Incidence of thrombotic complications in critically ill ICU patients with COVID-19.Thromb Res 2020; 191: 145147. DOI: $10.1016 /$ j.thromres.2020.04.013

[22] Chang JC. Acute respiratory distress syndrome as an organ phenotype of vascular microthrombotic disease: Based on hemostatic theory and endothelial molecular pathogenesis. Clin Appl Thromb Hemost. 2109; 25: 1076029619887437

DOI: $10.1177 / 1076029619887437$ 